\title{
Form, size and volumetric expansion of Adzuki beans (Vigna angularis) during soaking
}

\author{
Forma, tamanho e expansão volumétrica do feijão adzuki (Vigna angularis) durante a embebição
}

\author{
Udenys Cabral MENDES ${ }^{1 *}$, Osvaldo RESENDE ${ }^{1}$ Dieimisson Paulo ALMEIDA ${ }^{1}$
}

\begin{abstract}
This study analyzed the variation in shape and size of Adzuki beans during soaking at different temperatures. In addition, different mathematical models were fitted to the experimental values of volumetric expansion, selecting the best one. Grains of Adzuki beans (Vigna angularis) with moisture content of approximately 0.25 (decimal d.b.) were manually harvested; they were, then, dried to 0.128 (decimal d.b.). The beans were subjected to soaking in distilled water at the temperatures $18 \pm 1,27 \pm 1,36 \pm 1$, and $45 \pm 1{ }^{\circ} \mathrm{C}$, in five repetitions. Recipients containing $80 \mathrm{~mL}$ of distilled water and $20 \mathrm{~g}$ of beans for each sample were used. The samples were periodically weighed in order to determine the water absorption. After that, the samples were removed from the recipients and placed on filter papers for two minutes to drain the surface water. Water absorption continued until the beans reached the saturation moisture content. It was concluded that, the form of the Adzuki beans was altered regularly, the orthogonal axes expanded differentially in the radial and axial directions, and that the linear model appropriately described the volumetric expansion of the Adzuki beans, among the series of models analyzed for the temperatures $18,27,36$ and $45{ }^{\circ} \mathrm{C}$.

Keywords: physical properties; moisture content; mathematical modeling.
\end{abstract}

\section{Resumo}

Objetivou-se com o presente trabalho analisar a variação da forma e tamanho dos grãos de feijão adzuki durante a embebição em diferentes temperaturas. Paralelamente, foram ajustados modelos matemáticos aos valores experimentais da expansão volumétrica e selecionado aquele que melhor representou o fenômeno. Foram utilizados grãos de feijão adzuki (Vigna angularis), colhidos manualmente, com teor de água de 0,25 (decimal b.s.) e secos até 0,128 (decimal b.s.). O feijão foi submetido à embebição em água destilada nas temperaturas $18 \pm 1,27 \pm 1$, $36 \pm 1$ e $45 \pm 1^{\circ} \mathrm{C}$, em cinco repetições. Foram utilizados recipientes contendo $80 \mathrm{~mL}$ de água destilada juntamente com $20 \mathrm{~g}$ de produto em cada amostra. As amostras foram pesadas, periodicamente, para obtenção da absorção de água. Os grãos foram retirados dos recipientes e colocados sobre papel de filtro para escorrimento da água superficial por dois minutos. A absorção de água prosseguiu até que o produto atingisse o teor de água de saturação. Conclui-se que a forma do feijão adzuki altera regularmente e os eixos ortogonais expandem-se diferencialmente nas direções radial e axial e que o modelo Linear descreve adequadamente a expansão volumétrica do feijão adzuki, dentre a série de modelos analisados nas temperaturas $18,27,36$ e $45^{\circ} \mathrm{C}$.

Palavras-chave: propriedades físicas; teor de água; modelagem matemática.

\section{Introduction}

Beans are cultivated in almost every tropical and subtropical climate country, and it is extremely important for human feeding, fundamentally due to its low cost and nutritional balance. It is the major protein source for the least favored social classes, and it is used in place of meats and other protein products, and along with rice becomes their staple diet (RIOS; ABREU; CORRÊA, 2003; FERNANDES; SOUZA FILHO, 2001). The Vigna genus comprises about 160 species, out of which only seven are commercially grown. Among these, Adzuki beans (Vigna angularis) are mostly grown in Asia (VIEIRA; VIEIRA; ANDRADE, 1992), and are mostly used in China, Japan and Korea. Japan is the major producer and importer of Adzuki beans, cultivating an area around 100 thousand hectares. No precise data about producers, production or grown area with this type of beans exist in Brazil, where is consumed in Japanese colonies, especially as sweets and uncountable oriental delicacies.
The increase in grain moisture content, besides provoking its expansion, it directly influences the alteration in the physical properties during soaking. Therefore, the knowledge about physical properties is of such fundamental importance in the optimization of industrial processes, project and equipment measurement employed in the post harvest processing.

Researchers have presented studies on the evaluation of the main physical properties of agricultural products, demonstrating its practical application in projects of machines and structures. Recent scientific discoveries have improved the manipulation and processing of biological materials with the utilization of mechanical processes: thermal, electrical, optical, and so on; but still very little is known about physical characteristics of the products (AMIN; OSSAIN; ROY, 2004).

Size and form are specific characteristics of each product, genetically defined, that can be influenced by the environment

Received 24/11/2009

Accepted 4/4/2010 (004483)

1 Laboratório de Pós-colheita de Produtos Vegetais, Instituto Federal Goiano, Campus Rio verde, Rod. Sul Goiana, Km 1, zona rural, CEP 75901-970, Rio Verde, GO, Brasil, e-mail: udenys-agro@hotmail.com

${ }^{*}$ Corresponding author 
during and after its formation period, which influences the other physical properties of the product. These data are used for the size and form measurement of fruits and for the sieves in equipment destined to separation and classification (SILVA; CORRÊA, 2000).

Technological characteristics of the bean grain, especially soaking and cooking time, are important factors affecting product quality, and are highly correlated (GUEVARA, 1990). Such characteristics can be affected by species and genetic composition of the grain, associated to environment production conditions, grain processing and storage (COELHO et al., 2007). According to Yousif et al. (2003), Adzuki beans present as an important characteristic the tenderness of the tegument after cooking, indicating an excellent cooking quality. Soaking of materials is a complex process that reconstitutes the original characteristics of the product, after contact with a liquid phase (BILBAO-SÁINZ; ANDRÉS; FITO, 2005).

During soaking, water diffuses to the inner parts of the product, increasing its volume. This volume expansion can occur differentially in the grain radial and axial directions (BAYRAM; ONER; KAYA, 2004), and it is mostly affected by the temperature of the soaking solution.

Bayram, Oner and Kaya (2004), analyzing dimension variation in soybean grains during soaking at different temperatures, found a product volume increase of 129.6 , 130.1 and $146.3 \%$ for the temperatures of 30,50 and $70{ }^{\circ} \mathrm{C}$, respectively. In contrast, Corrêa et al. (2007) evaluated volume expansion of common beans (Phaseolus vulgaris L.) during soaking at temperatures of $20,30,40$ and $50^{\circ} \mathrm{C}$ and observed a volume increase ranging from 222 to $242 \%$; also, these authors identified that common beans expand differently in the radial and axial directions, presenting non-uniform variation in their characteristic dimensions, which were greater for the smaller axis.

Water absorption by agricultural products subject to soaking processes, in general, increases with temperature increase and soaking time (BHATTACHARYA 1995; PAN; TANGRATANAVALEE, 2003; RESIO; AGUERRE; SUAREZ, 2003, 2005; BELLO; TOLABA; SUAREZ, 2004; BAYRAM; ONER; KAYA, 2004; RESENDE; CORRÊA, 2007; COELHO et al., 2008). The temperature effect during soaking has been studied for several agricultural products, such as corn (BHATTACHARYA, 1995; VERMA; PRASAD, 1999), common beans (ABU-GHANNAM; MCKENNA, 1997; RESENDE; CORRÊA, 2007; COELHO, et al., 2008), soybeans (PAN; TANGRATANAVALEE, 2003; BAYRAM; ONER; KAYA, 2004), wheat (BAYRAM; ONER; EREN, 2004), rice (BELLO; TOLABA; SUAREZ, 2004) and amaranth seeds (RESIO; AGUERRE; SUAREZ, 2005).

Water movement in the solid can be explained by different mechanisms. Several authors have proposed that the major mechanism of water transport is liquid diffusion (FORTES; OKOS, 1980; GEANKOPLIS, 1983). Diffusion occurs in the fine structure solids and in capillaries or pores and in the small orifices filled with vapor. However, diffusion theory does not consider shrinking, hardening of the tegument (hard skin) and sorption isotherms (BARBOSA-CÁNOVAS; VEJA-MERCADO, 2000).
Resende and Corrêa (2007) determined the diffusion coefficient during the soaking of common beans (Phaseolus vulgaris $\mathrm{L}$.), considering the volumetric expansion, and found values of $1.07 \times 10^{-9}, 1.30 \times 10^{-9}, 1.58 \times 10^{-9}$ and $1.41 \times 10^{-9} \mathrm{~m} /$ second, at temperatures $20,30,40$ and $50{ }^{\circ} \mathrm{C}$, respectively. These researchers found that the relationship between the diffusion coefficient and the temperature can be described by the Arrhenius' equation, and presented activation energy for liquid diffusion in common bean grains of $6.748 \mathrm{~kJ} \cdot \mathrm{mol}^{-1}$.

Mathematical modeling is essential to predict and simulate the performance of materials subjected to a given process. There are several mathematical models in the literature expressing the soaking phenomenon in agricultural products. However, most models are based on diffusion laws and involve numerous functions and parameters that hardly represent water absorption in a simple manner (ABU-GHANNAM; MCKENNA, 1997). Thus, Peleg (1988) proposed an empirical model to simplify the description of water absorption by grains and cereals. This model has been accepted and used by several researchers to represent this phenomenon (ABU-GHANNAM; MCKENNA, 1997; TURHAN; SAYAR; GUNASEKARAN, 2002; PAN; TANGRATANAVALEE, 2003; RESENDE; CORRÊA, 2007).

Therefore, this study analyzed the variation in shape and size of Adzuki beans during soaking at different temperatures, as well as the fit of different mathematical models to the experimental data on volume expansion, selecting the one that best represented this phenomenon.

\section{Materials and methods}

This study was carried out at the Vegetable Produce Post-Harvest Laboratory and the Seed Quality Laboratory of at 'Instituto Federal Goiano - Campus Rio Verde - IFGoiano Campus Rio Verde', located in Rio Verde, State of Goias.

Grains of Adzuki beans (Vigna angularis) cultivated in the Summer 2007/2008 at the experimental area of 'IFGoiano Campus Rio Verde', in Rio Verde, State of Goias and manually harvested with approximately 0.25 (decimal b.s.) moisture and dried until 0.128 (decimal b.s.) were used in this experiment.

The beans were subjected to soaking in distilled water at $18 \pm 1,27 \pm 1,36 \pm 1$ and $45 \pm 1{ }^{\circ} \mathrm{C}$, in five replicates. Plastic containers $(100 \mathrm{~mL}$ capacity) containing $80 \mathrm{~mL}$ of distilled water with $20 \mathrm{~g}$ of product in each sample, in a mass relation of $4 / 1$, were used. Water absorption was monitored by periodically weighing the samples, removing them from the containers, and placing them over filter paper in order to remove surface water during approximately two minutes. Water absorption by Adzuki beans proceeded until the product reached its moisture saturation contents. Grains were randomly chosen and placed in a recipient with $20 \mathrm{~mL}$ of distilled water.

The shape and size of the Adzuki beans, considered as spheroids, were analyzed regarding sphericity, roundness and volume using the characteristic dimensions in ten grains, orthogonal axis, obtained through a digital caliper with $0.01 \mathrm{~mm}$ resolution. 
The sphericity of the beans was determined according to the expression described by Mohsenin (1986) (Equation 1):

$E_{S}=\left[{\frac{(a \cdot b \cdot c)^{1 / 3}}{a}}^{1 / 3} \cdot 100\right.$

where, $\mathrm{E}_{\mathrm{S}}$ : sphericity, \%; a: longest grain axis dimension, $\mathrm{mm}$; $\mathrm{b}$ : medium grain axis dimension, $\mathrm{mm}$; $\mathrm{c}$ : smallest grain axis dimension, mm.

The circularities of Adzuki beans, obtained for the three projection positions, were determined for each of them, as shown in Figure 1, and calculated by the following expression (MOHSENIN, 1986) (Equation 2):

$C_{r}=\frac{d_{i}}{d_{c}} \cdot 100$

where, $\mathrm{C}_{\mathrm{r}}$ : circularity, $\%$; $\mathrm{d}_{\mathrm{i}}$ : diameter of the largest inscribed circle, $m ; d_{c}$ : diameter of the smallest circumscribed circle, $m$.
The expansion indices were obtained by the relationship between the characteristic dimension for each moisture content $(\mathrm{a}, \mathrm{b}$ and $\mathrm{c}$ ) and the initial dimension for each orthogonal axis $\left(a_{0}, b_{o}\right.$ and $\left.c_{o}\right)$.

The volume expansion of the grains during product soaking was determined by the relation between the grain volume for each water content and the initial volume (Equation 3):

$$
\lambda=\frac{V_{g}}{V_{g o}}
$$

where, $\lambda$ : Grain volume expansion, decimal; $\mathrm{V}_{\mathrm{g}}$ : Grain volume for each water contents, $\mathrm{m}^{3} ; \mathrm{V}_{\mathrm{go}}$ : Grain initial volume, $\mathrm{m}^{3}$.

Mathematical models were fitted to the experimental data of volume expansion of Adzuki beans to represent the phenomenon, by the expressions listed in Table 1 (Equations 4-9).

Peleg's model and the variation of constants in function of the soaking temperature were adjusted by regression analysis,

Table 1. Mathematical models used to adjust the experimental data of volume expansion of Adzuki beans.

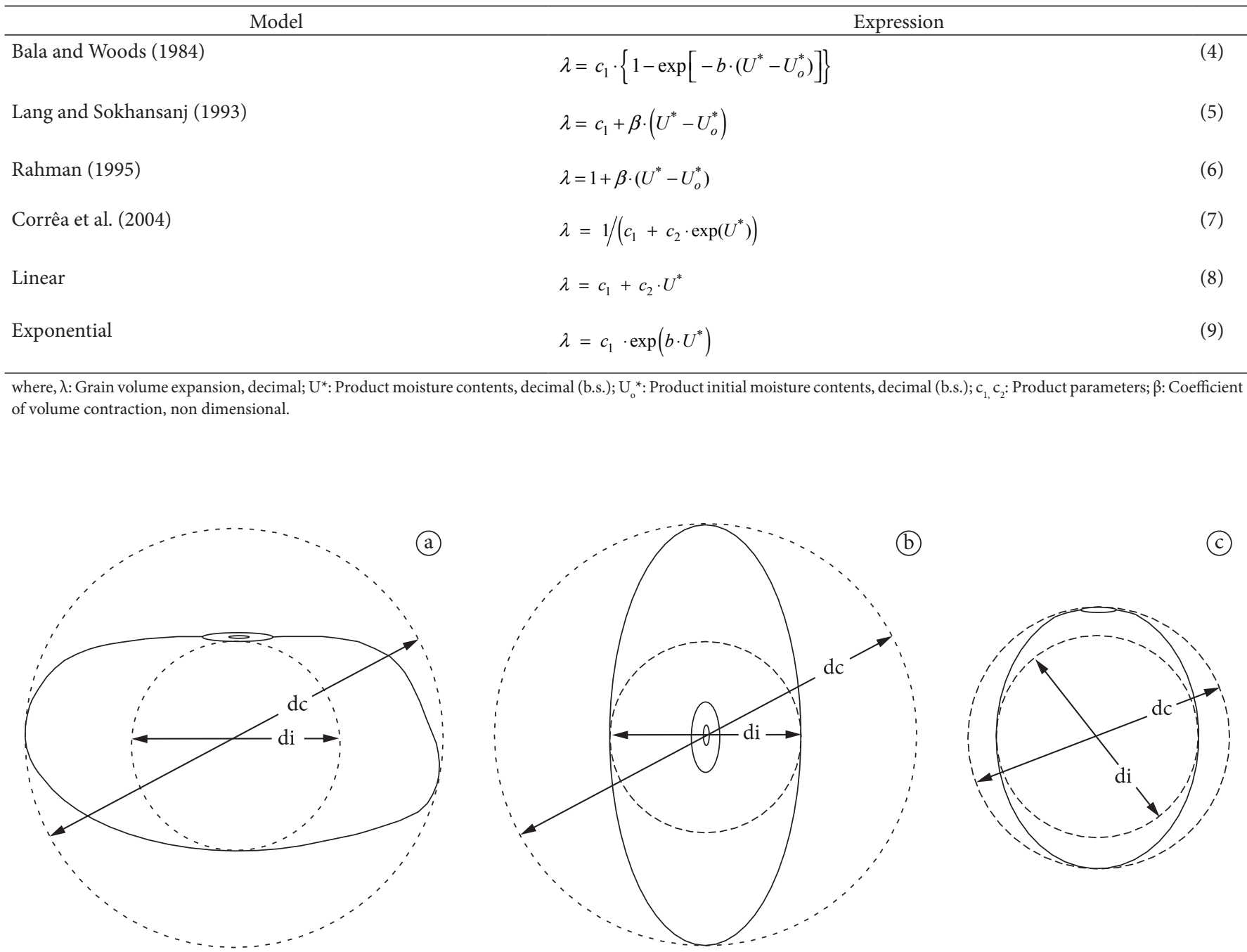

Figure 1. Schematic representation of Adzuki bean grains in three projection positions, a) longest axis, $\mathrm{C}_{\mathrm{r} 1}$; and b) medium axis, $\mathrm{C}_{\mathrm{r} 2}$; $\mathrm{c}$ ) smallest axis, $\mathrm{C}_{\mathrm{r} 3}$. 
using the Gauss Newton's method, with the aid of the program STATISTICA 5.0. The influence of fit for each model considered the significance of the regression coefficient by the $T$ test, at $1 \%$ probability; the magnitude of the determination coefficient $\left(R^{2}\right)$; the magnitude of the relative average error $(\mathrm{P})$; and the standard error of the estimate (SE). The relative average error and the standard error of the estimate were calculated according to the expressions (Equations 10 and 11):

$$
\begin{aligned}
& P=\frac{100}{n} \sum \frac{|Y-\hat{Y}|}{Y} \\
& S E=\sqrt{\frac{\sum(Y-\hat{Y})^{2}}{G L R}}
\end{aligned}
$$

where, Y: Experimentally observed value; $\hat{Y}$ : Value estimated by the model; $\mathrm{n}$ : Number of experimental observations; GLR: Degrees of freedom of the model (number of observations minus the number of parameters in the model).

\section{Results and discussion}

According to Tables 2 and 3 , the saturation moisture content increased with the increase of the soaking temperatures, with the exception of $27^{\circ} \mathrm{C}$, presenting values of $1.336,1.179,1.549$ and 1.574 (decimal b.s.) for the temperatures of $18,27,36$ and $45^{\circ} \mathrm{C}$, respectively. Coelho et al. (2008) also verified that the increase of the soaking water temperature increased the capacity of maximum soaking of five varieties of beans (Phaseolus vulgaris).

It was observed that Adzuki beans grains expanded differentially in the radial and axial directions, presenting non-uniform variations in its characteristic dimensions.

The volumetric expansion indices for Adzuki beans soaking in the range of 18 to $45^{\circ} \mathrm{C}$ were 33.6 to $55.5 \%$ for the longest axis, 13.9 to $20.9 \%$ for the medium axis and 23.3 to $34.5 \%$ for the smallest axis. Thus, the greatest expansion index was observed for the orthogonal axis "a", differently from the results observed by Corrêa et al. (2007) for common red beans (Phaseolus vulgaris L.), during soaking at temperatures 20, 30, 40 and $50{ }^{\circ} \mathrm{C}$, where the greatest expansion was observed in axis "c". Also, it can be observed in Tables 2 and 3 that the Adzuki beans shape changed regularly during soaking at temperatures $18,27,36$ and $45^{\circ} \mathrm{C}$.

Thus, the circularities according to the longest axis $\left(\mathrm{C}_{\mathrm{r} 1}\right)$ and the medium axis $\left(\mathrm{C}_{\mathrm{r} 2}\right)$ decreased during soaking while the

Table 2. Average dimensions of the orthogonal axes $(\mathrm{a} ; \mathrm{b} ; \mathrm{c})$, expansion indices $\left(\mathrm{a} / \mathrm{a}_{\mathrm{o}} ; \mathrm{b} / \mathrm{b}_{\mathrm{o}} ; \mathrm{c} / \mathrm{c}_{\mathrm{o}}\right)$, sphericity $\left(\mathrm{E}_{\mathrm{s}}\right)$ and circularities of the longest

\begin{tabular}{|c|c|c|c|c|c|c|c|c|c|c|}
\hline \multicolumn{11}{|c|}{ Temperature $18 \pm 1^{\circ} \mathrm{C}$} \\
\hline \multirow{2}{*}{$\begin{array}{l}\text { Moisture content } \\
\text { (b.s.) }\end{array}$} & \multicolumn{3}{|c|}{ Orthogonal axes $(\mathrm{mm})$} & \multirow{2}{*}{$\begin{array}{l}\mathrm{a} / \mathrm{a}_{\mathrm{o}} \\
(\%)\end{array}$} & \multirow{2}{*}{$\begin{array}{l}\mathrm{b} / \mathrm{b}_{\mathrm{o}} \\
(\%)\end{array}$} & \multirow{2}{*}{$\begin{array}{l}\mathrm{c} / \mathrm{c}_{\mathrm{o}} \\
(\%)\end{array}$} & \multirow{2}{*}{$\begin{array}{l}\mathrm{C}_{\mathrm{r} 1} \\
(\%)\end{array}$} & \multirow{2}{*}{$\begin{array}{l}\mathrm{C}_{\mathrm{r} 2} \\
(\%)\end{array}$} & \multirow{2}{*}{$\begin{array}{l}\mathrm{C}_{\mathrm{r} 3} \\
(\%)\end{array}$} & \multirow{2}{*}{$\begin{array}{c}\mathrm{E}_{\mathrm{s}} \\
(\%)\end{array}$} \\
\hline & $\mathrm{a}$ & $\mathrm{b}$ & $\mathrm{c}$ & & & & & & & \\
\hline 0.128 & 7.47 & 4.19 & 3.02 & 100.0 & 100.0 & 100.0 & 56.0 & 40.4 & 72.2 & 61.0 \\
\hline 0.189 & 7.49 & 4.18 & 3.17 & 100.3 & 99.8 & 104.8 & 55.7 & 42.3 & 75.8 & 61.8 \\
\hline 0.206 & 7.51 & 4.17 & 3.16 & 100.5 & 99.5 & 104.4 & 55.4 & 42.0 & 75.8 & 61.5 \\
\hline 0.274 & 7.60 & 4.05 & 3.14 & 101.7 & 96.7 & 104.0 & 53.3 & 41.4 & 77.6 & 60.4 \\
\hline 0.351 & 7.69 & 4.28 & 3.20 & 102.8 & 102.2 & 105.7 & 55.6 & 41.6 & 74.7 & 61.4 \\
\hline 0.469 & 8.04 & 4.27 & 3.34 & 107.6 & 102.0 & 110.4 & 53.1 & 41.5 & 78.1 & 60.4 \\
\hline 0.609 & 8.25 & 4.27 & 3.42 & 110.4 & 102.0 & 113.1 & 51.7 & 41.4 & 80.1 & 59.8 \\
\hline 0.756 & 8.65 & 4.51 & 3.54 & 115.7 & 107.8 & 117.0 & 52.2 & 40.9 & 78.4 & 59.8 \\
\hline 0.908 & 8.91 & 4.53 & 3.57 & 119.2 & 108.2 & 118.1 & 50.9 & 40.1 & 78.8 & 58.9 \\
\hline 1.031 & 9.14 & 4.60 & 3.66 & 122.3 & 110.0 & 120.9 & 50.4 & 40.0 & 79.4 & 58.6 \\
\hline 1.108 & 9.36 & 4.64 & 3.76 & 125.3 & 110.9 & 124.3 & 49.6 & 40.1 & 81.0 & 58.4 \\
\hline 1.164 & 9.47 & 4.69 & 3.68 & 126.7 & 112.0 & 121.8 & 49.5 & 38.9 & 78.5 & 57.7 \\
\hline 1.223 & 9.66 & 4.64 & 3.64 & 129.2 & 110.9 & 120.4 & 48.1 & 37.7 & 78.4 & 56.6 \\
\hline 1.288 & 9.90 & 4.72 & 3.73 & 132.5 & 112.8 & 123.4 & 47.7 & 37.7 & 79.0 & 56.4 \\
\hline 1.336 & 9.99 & 4.81 & 3.76 & 133.6 & 115.0 & 124.5 & 48.2 & 37.7 & 78.2 & 56.6 \\
\hline \multicolumn{11}{|c|}{ Temperature $27 \pm 1^{\circ} \mathrm{C}$} \\
\hline 0.128 & 7.63 & 4.52 & 3.39 & 100.0 & 100.0 & 100.0 & 59.2 & 44.5 & 75.1 & 64.1 \\
\hline 0.196 & 7.63 & 4.58 & 3.40 & 100.1 & 101.5 & 100.3 & 60.1 & 44.6 & 74.2 & 64.5 \\
\hline 0.234 & 7.76 & 4.58 & 3.44 & 101.7 & 101.4 & 101.4 & 59.1 & 44.4 & 75.1 & 64.0 \\
\hline 0.311 & 7.90 & 4.61 & 3.48 & 103.6 & 102.1 & 102.6 & 58.3 & 44.1 & 75.6 & 63.6 \\
\hline 0.379 & 8.15 & 4.67 & 3.53 & 106.9 & 103.5 & 104.0 & 57.3 & 43.3 & 75.5 & 62.8 \\
\hline 0.481 & 8.54 & 4.81 & 3.62 & 112.0 & 106.5 & 106.6 & 56.3 & 42.4 & 75.2 & 62.0 \\
\hline 0.615 & 8.88 & 4.79 & 3.77 & 116.4 & 106.1 & 111.1 & 53.9 & 42.5 & 78.7 & 61.2 \\
\hline 0.755 & 9.12 & 5.44 & 3.82 & 119.5 & 120.4 & 112.4 & 59.7 & 41.9 & 70.2 & 63.0 \\
\hline 0.892 & 9.44 & 5.04 & 3.97 & 123.8 & 111.5 & 117.1 & 53.4 & 42.1 & 78.9 & 60.8 \\
\hline 1.006 & 9.50 & 5.11 & 4.05 & 124.6 & 113.2 & 119.2 & 53.8 & 42.6 & 79.2 & 61.2 \\
\hline 1.083 & 9.99 & 5.12 & 4.07 & 130.9 & 113.5 & 120.0 & 51.3 & 40.8 & 79.5 & 59.4 \\
\hline 1.179 & 10.33 & 5.14 & 4.18 & 135.4 & 113.9 & 123.3 & 49.8 & 40.5 & 81.3 & 58.7 \\
\hline
\end{tabular}
axis $\left(\mathrm{C}_{\mathrm{r} 1}\right)$, medium axis $\left(\mathrm{C}_{\mathrm{r} 2}\right)$ and smallest axis $\left(\mathrm{C}_{\mathrm{r} 3}\right)$, during soaking of Adzuki beans at the temperatures $18 \pm 1$ and $27 \pm 1^{\circ} \mathrm{C}$. 
Table 3. Average dimensions of the orthogonal axes $(\mathrm{a} ; \mathrm{b} ; \mathrm{c})$, expansion indices $\left(\mathrm{a} / \mathrm{a}_{\mathrm{o}} ; \mathrm{b} / \mathrm{b}_{\mathrm{o}} ; \mathrm{c} / \mathrm{c}_{\mathrm{o}}\right)$, sphericity $\left(\mathrm{E}_{\mathrm{s}}\right)$ and circularities of the longest axis $\left(\mathrm{C}_{\mathrm{r} 1}\right)$, medium axis $\left(\mathrm{C}_{\mathrm{r} 2}\right)$ and smallest axis $\left(\mathrm{C}_{\mathrm{r} 3}\right)$, during soaking of Adzuki beans at temperatures $36 \pm 1$ and $45 \pm 1^{\circ} \mathrm{C}$.

\begin{tabular}{|c|c|c|c|c|c|c|c|c|c|c|}
\hline \multicolumn{11}{|c|}{ Temperature $36 \pm 1^{\circ} \mathrm{C}$} \\
\hline \multirow{2}{*}{$\begin{array}{l}\text { Moisture content } \\
\text { (b.s.) }\end{array}$} & \multicolumn{3}{|c|}{ Orthogonal axis (mm) } & \multirow{2}{*}{$\begin{array}{l}\mathrm{a} / \mathrm{a}_{\mathrm{o}} \\
(\%)\end{array}$} & \multirow{2}{*}{$\begin{array}{l}\mathrm{b} / \mathrm{b}_{\mathrm{o}} \\
(\%)\end{array}$} & \multirow{2}{*}{$\begin{array}{l}\mathrm{c} / \mathrm{c}_{\mathrm{o}} \\
(\%)\end{array}$} & \multirow[t]{2}{*}{$\mathrm{C}_{\mathrm{r} 1}(\%)$} & \multirow[t]{2}{*}{$\mathrm{C}_{\mathrm{r} 2}(\%)$} & \multirow[t]{2}{*}{$\mathrm{C}_{\mathrm{r} 3}(\%)$} & \multirow[t]{2}{*}{$\mathrm{E}_{\mathrm{s}}(\%)$} \\
\hline & $\mathrm{a}$ & $\mathrm{b}$ & c & & & & & & & \\
\hline 0.128 & 7.74 & 4.46 & 3.29 & 100.0 & 100.0 & 100.0 & 57.6 & 42.5 & 73.7 & 62.5 \\
\hline 0.195 & 7.76 & 4.50 & 3.30 & 100.2 & 100.9 & 100.4 & 58.0 & 42.6 & 73.4 & 62.7 \\
\hline 0.260 & 7.78 & 4.52 & 3.31 & 100.4 & 101.3 & 100.7 & 58.1 & 42.6 & 73.2 & 62.8 \\
\hline 0.384 & 8.14 & 4.54 & 3.36 & 105.1 & 101.7 & 102.2 & 55.8 & 41.3 & 74.1 & 61.3 \\
\hline 0.549 & 8.75 & 4.60 & 3.57 & 113.0 & 103.1 & 108.5 & 52.6 & 40.8 & 77.6 & 59.9 \\
\hline 0.774 & 9.61 & 4.96 & 3.82 & 124.1 & 111.2 & 116.1 & 51.6 & 39.8 & 77.0 & 59.0 \\
\hline 0.982 & 10.27 & 5.13 & 3.99 & 132.6 & 115.0 & 121.2 & 50.0 & 38.8 & 77.7 & 57.9 \\
\hline 1.160 & 10.93 & 5.23 & 4.10 & 141.2 & 117.1 & 124.5 & 47.8 & 37.5 & 78.4 & 56.4 \\
\hline 1.351 & 11.41 & 5.29 & 4.20 & 147.3 & 118.6 & 127.8 & 46.4 & 36.9 & 79.5 & 55.5 \\
\hline 1.448 & 11.54 & 5.32 & 4.29 & 149.0 & 119.3 & 130.5 & 46.1 & 37.2 & 80.6 & 55.6 \\
\hline 1.491 & 11.73 & 5.39 & 4.42 & 151.4 & 120.8 & 134.4 & 45.9 & 37.7 & 82.1 & 55.7 \\
\hline 1.549 & 12.04 & 5.39 & 4.42 & 155.5 & 120.9 & 134.5 & 44.8 & 36.7 & 82.0 & 54.8 \\
\hline \multicolumn{11}{|c|}{ Temperature $45 \pm 1{ }^{\circ} \mathrm{C}$} \\
\hline 0.128 & 8.02 & 4.57 & 3.45 & 100.0 & 100.0 & 100.0 & 57.0 & 43.0 & 75.5 & 62.6 \\
\hline 0.189 & 8.04 & 4.72 & 3.48 & 100.3 & 103.3 & 100.7 & 58.7 & 43.2 & 73.7 & 63.3 \\
\hline 0.273 & 8.17 & 4.67 & 3.51 & 101.8 & 102.2 & 101.8 & 57.1 & 43.0 & 75.3 & 62.6 \\
\hline 0.420 & 8.73 & 4.74 & 3.65 & 108.8 & 103.8 & 105.6 & 54.3 & 41.8 & 76.9 & 61.0 \\
\hline 0.623 & 9.61 & 4.87 & 3.91 & 119.8 & 106.5 & 113.2 & 50.6 & 40.6 & 80.3 & 59.0 \\
\hline 0.859 & 10.42 & 5.29 & 4.16 & 129.9 & 115.9 & 120.5 & 50.8 & 39.9 & 78.5 & 58.7 \\
\hline 1.086 & 11.17 & 5.30 & 4.31 & 139.3 & 116.1 & 124.8 & 47.5 & 38.5 & 81.2 & 56.8 \\
\hline 1.245 & 11.70 & 5.40 & 4.40 & 145.9 & 118.1 & 127.6 & 46.1 & 37.6 & 81.6 & 55.8 \\
\hline 1.341 & 11.91 & 5.41 & 4.44 & 148.5 & 118.3 & 128.6 & 45.4 & 37.3 & 82.1 & 55.3 \\
\hline 1.416 & 11.98 & 5.43 & 4.48 & 149.3 & 118.9 & 129.7 & 45.4 & 37.4 & 82.4 & 55.3 \\
\hline 1.451 & 12.07 & 5.48 & 4.53 & 150.5 & 119.9 & 131.2 & 45.4 & 37.5 & 82.7 & 55.3 \\
\hline 1.513 & 12.18 & 5.51 & 4.54 & 151.8 & 120.6 & 131.6 & 45.3 & 37.3 & 82.4 & 55.3 \\
\hline 1.574 & 12.28 & 5.50 & 4.58 & 153.0 & 120.3 & 132.8 & 44.8 & 37.3 & 83.4 & 55.1 \\
\hline
\end{tabular}

circularity analyzed by the smallest axis $\left(\mathrm{C}_{\mathrm{r} 3}\right)$ increased, for all four temperatures evaluated. Therefore, it can be noted that the increase of the grains volume during the soaking happened in an irregular way for the orthogonal axes, resulting in a variation of the circularity values. Sphericity decreased during soaking for all temperatures analyzed, presenting the smallest values at temperatures 36 and $45{ }^{\circ} \mathrm{C}$. Corrêa et al. (2007) observed different values for common red beans (Phaseolus vulgaris L.), since the shape was changed irregularly during soaking at the temperature range of 20 to $50^{\circ} \mathrm{C}$.

In contrast, Bayram, Oner and Kaya (2004) found volume increases of 129.6 to $146.3 \%$ for soybeans subjected to soaking at 30 to $70^{\circ} \mathrm{C}$, while wheat grain volume increased from 131.6 to $180.4 \%$ during soaking at temperatures 87 and $97^{\circ} \mathrm{C}$ (BAYRAM; ONER; EREN, 2004).

Tables 4 and 5 present the values of the determination coefficient, relative and estimated average errors, and trend of residue distribution for all six models analyzed during Adzuki beans soaking at the different temperatures.

The models adjusted to the experimental data presented determination coefficients $\left(R^{2}\right)$ above $97 \%$, except for the
Corrêa (7) model (Table 4). In general, the greatest $\mathrm{R}^{2}$ values were observed for the models of Lang and Sokhansanj (5), Rahman (6) and Linear (8). The models of Lang and Sokhansanj (5) and Linear (8) presented the smallest magnitudes of the estimated average error (SE), for the data analyzed, except for the temperature $18{ }^{\circ} \mathrm{C}$, where Lang and Sokhansanj (5) and Exponential (9) models also showed low values of SE. The models presented relative average error $(\mathrm{P})$ below $10 \%$, what, according to Mohapatra and Rao (2005) indicates adequate description of the phenomenon, except for the model by Corrêa (7) at temperatures 36 and $45^{\circ} \mathrm{C}$. It can be seen in Table 5 that the Linear (8) model presented, for all four soaking temperatures, a random distribution of residues; thus, resulting in satisfactory fit to the data of volume expansion of Adzuki beans. Therefore, analyzing these statistical parameters, it can be stated that the Linear (8) model presented the best indices, and it was considered the most adequate to represent the volume expansion of Adzuki beans grains. Resende and Corrêa (2007) also found that the Linear model adequately represented the phenomenon of volume expansion of common red beans (Phaseulos vulgaris) during soaking at temperatures $20,30,40$ and $50^{\circ} \mathrm{C}$. Figure 2 presents the example of random and biased residue distribution. 
Table 4. Determination coefficients $\left(\mathrm{R}^{2}, \%\right)$, relative average error $(\mathrm{P}, \%)$ and estimated error (SE, decimal), for the six models adjusted to the volume expansion data, during Adzuki beans soaking at temperatures 18, 27, 36 and $45^{\circ} \mathrm{C}$.

\begin{tabular}{|c|c|c|c|c|c|c|c|c|c|c|c|c|}
\hline \multirow[t]{3}{*}{ Model } & \multicolumn{12}{|c|}{ Temperature $\left({ }^{\circ} \mathrm{C}\right)$} \\
\hline & \multicolumn{3}{|c|}{18} & \multicolumn{3}{|c|}{27} & \multicolumn{3}{|c|}{36} & \multicolumn{3}{|c|}{45} \\
\hline & $\mathrm{R}^{2}$ & SE & $\mathrm{P}$ & $\mathrm{R}^{2}$ & SE & $\mathrm{P}$ & $\mathrm{R}^{2}$ & SE & $\mathrm{P}$ & $\mathrm{R}^{2}$ & SE & $\mathrm{P}$ \\
\hline$(4)$ & 98.43 & 0.045 & 2.7 & 96.21 & 0.067 & 3.8 & 98.07 & 0.088 & 5.3 & 98.07 & 0.084 & 4.9 \\
\hline (5) & 98.98 & 0.036 & 2.27 & 98.39 & 0.043 & 2.02 & 99.05 & 0.062 & 3.39 & 99.33 & 0.096 & 5.08 \\
\hline$(6)$ & 98.55 & 0.041 & 2.34 & 98.39 & 0.048 & 2.82 & 99.05 & 0.088 & 4.73 & 97.51 & 0.123 & 6.38 \\
\hline (7) & 92.51 & 0.102 & 4.35 & 90.64 & 0.105 & 6.03 & 90.19 & 0.199 & 11.12 & 85.73 & 0.229 & 12.25 \\
\hline
\end{tabular}

Table 5. Behavior of residue distribution, random or biased, for the six models analyzed, during Adzuki beans soaking at temperatures 18,27 , 36 and $45^{\circ} \mathrm{C}$.

\begin{tabular}{|c|c|c|c|c|}
\hline \multirow[t]{2}{*}{ Model } & \multicolumn{4}{|c|}{ Temperature $\left({ }^{\circ} \mathrm{C}\right)$} \\
\hline & 18 & 27 & 36 & 45 \\
\hline Bala and Woods & Random & Random & Random & Biased \\
\hline Lang and Sokhansanj & Random & Random & Random & Biased \\
\hline Rahman & Random & Random & Biased & Biased \\
\hline Corrêa & Biased & Biased & Biased & Biased \\
\hline Linear & Random & Random & Random & Random \\
\hline Exponential & Random & Random & Random & Biased \\
\hline
\end{tabular}

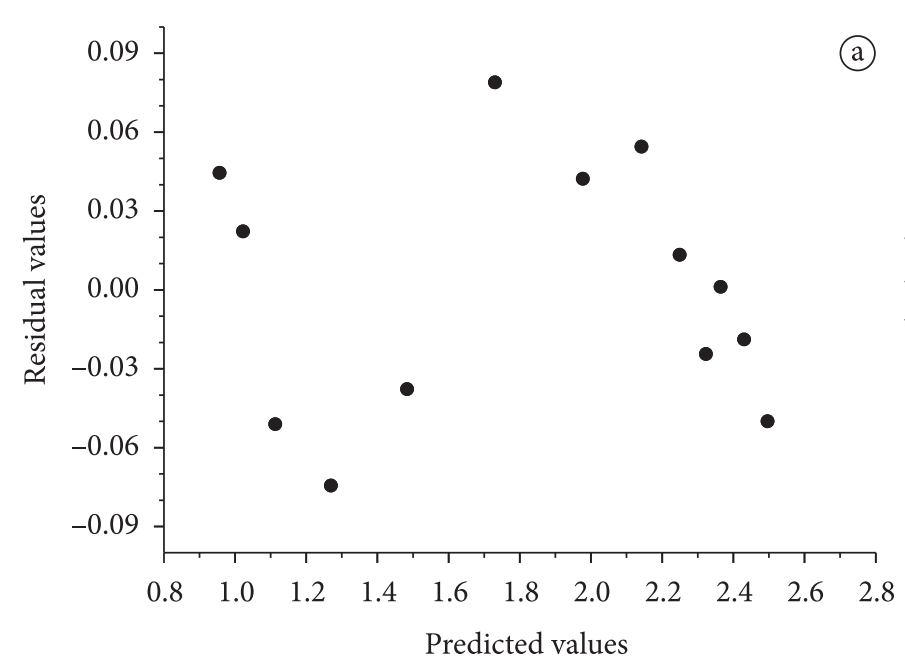

Figure 2. Example of residue distribution random a) or biased b).

\section{Conclusions}

For the conditions of this study, it can be concluded that the shape of Adzuki beans changes regularly and the orthogonal axes expand differentially in the radial and axial directions during soaking at temperatures $18,27,36$ and $45^{\circ} \mathrm{C}$. Based on statistical parameters, within the series of models analyzed, the volume expansion of Adzuki beans grains can be described by the simplest model, that is, the linear one.

\section{Acknowledgements}

The authors are grateful to 'Instituto Federal de Educação. Ciência e Tecnologia Goiano - Campus Rio Verde

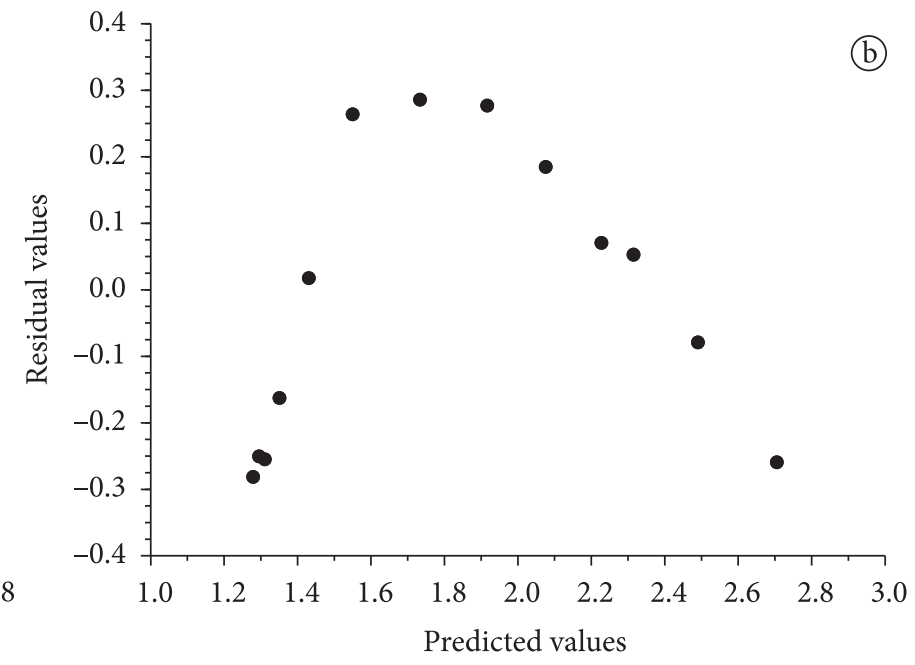

(IFGoiano - Campus Rio Verde)' and to 'Conselho Nacional de Desenvolvimento Científico e Tecnológico (CNPq)' for the financial support to this study.

\section{References}

ABU-GHANNAM, N.; MCKENNA, B. The application of Peleg's equation to model water absorption during the soaking of red kidney beans (Phaseolus vulgaris L.). Journal of Food Engineering, v. 32, n. 4, p. 391-401, 1997. http://dx.doi.org/10.1016/S02608774(97)00034-4

AMIN, M. N.; OSSAIN, M. A.; ROY, K. C. Effects of moisture content on some physical properties of lentil seeds. Journal of Food Engineering, v. 65, p. 83-87, 2004. 
BALA, B. K.; WOODS, J. L. Simulation of deep bed malt drying. Journal Agricultural Engineering Research, v. 30, n. 3, p. 235-244, 1984. http://dx.doi.org/10.1016/S0021-8634(84)80024-4

BARBOSA-CÁNOVAS, G. V.; VEJA-MERCADO, H. Deshidratación de alimentos. Ed. ACRIBIA S.A., 2000. 297 p.

BAYRAM, M.; ONER, M. D.; EREN, S. Effect of cooking time and temperature on the dimensions and crease of the wheat kernel during bulgur production. Journal of Food Engineering, v. 64, n. 1, p. 43-51, 2004. http://dx.doi.org/10.1016/j.jfoodeng.2003.09.011

BAYRAM, M.; ONER, M. D.; KAYA, A. Influence of soaking on the dimensions and color of soybean for bulgur production. Journal of Food Engineering, v. 61, n. 3, p. 331-339, 2004. http://dx.doi. org/10.1016/S0260-8774(03)00137-7

BELLO, M.; TOLABA, M. P.; SUAREZ, C. Factors affecting water uptake of rice grain during soaking. Food Science Technology, v. 37, n. 8, p. 811-816, 2004.

BHATTACHARYA, S. Kinetics of hydration of raw and roasted corn semolina. Journal of Food Engineering, v. 25, n. 1, p. 21-30, 1995. http://dx.doi.org/10.1016/0260-8774(95)93013-L

BILBAO-SÁINZ, C.; ANDRÉS, A.; FITO, P. Hydration kinetics of dried apple as affected by drying conditions. Journal of Food Engineering, v. 68, n. 3, p. 369-376, 2005. http://dx.doi. org/10.1016/j.jfoodeng.2004.06.012

COELHO, C. M. M. et al. Effect of phytate and storage conditions on the development of the hard to cook phenomenon in common beans. Journal of the Science of Food and Agriculture, v. 87, n. 7, p. 1237-1243, 2007.

COELHO, C. M. M. et al. Capacidade de cocção de grãos de feijão em função do genótipo e da temperatura da água de hidratação. Ciência e Agrotecnologia, v. 32, p. 1080-1086, 2008. http://dx.doi. org/10.1002/jsfa.2822

CORRÊA, P. C. et al. Forma, tamanho e modelagem da expansão volumétrica do feijão (Phaseolus vulgaris L.) durante a embebição. Revista Brasileira de Armazenamento, v. 32, n. 1, p. 70-78, 2007.

CORRÊA, P. C. et al. Mathematical modelling for representation of coffee berry volumetric shrinkage. In: INTERNATIONAL DRYING SYMPOSIUM - IDS, 14., 2004, São Paulo. Proceedings... Campinas: UNICAMP, 2004. v. A, p. 742-747.

FERNANDES, G. M. B.; SOUZA FILHO, B. F. Armazenamento de sementes de feijão na pequena propriedade. Rio de Janeiro: PESAGRO, 2001. 5 p.

FORTES, M.; OKOS, M. R. Drying theories. In: MUJUMDAR, A. S. Advances in Drying. New York: Hemisphere Publishing, 1980. v. 1.

GEANKOPLIS, C. J. Drying of process materials. In: GEANKOPLIS, C. J. Transport processes and unit operations. 2th ed. Boston: Allyn and Bacon,1983.

GUEVARA, L. L. V. Avaliação sensorial e inativação de lipoxigenase em feijão (Phaseolus vulgaris L.) armazenados em condições ambientais. 1990. 132 f. Dissertação (Mestrado em Ciências dos Alimentos)-Universidade Federal de Lavras, Lavras, 1990.
LANG, W.; SOKHANSANJ, S. Bulk volume shrinkage during drying of wheat and canola. Journal of Food Process Engineering, v. 16, n. 4, p. 305-314, 1993. http://dx.doi.org/10.1111/j.1745-4530.1993. tb00323. $\mathrm{x}$

MOHAPATRA, D.; RAO, P. S. A thin layer drying model of parboiled wheat. Journal of Food Engineering, v. 66, n. 4, p. 513-518, 2005. http://dx.doi.org/10.1016/j.jfoodeng.2004.04.023

MOHSENIN, N. N. Physical properties of plant and animal materials. New York: Gordon and Breach Publishers, 1986. 841 p.

PAN, Z.; TANGRATANAVALEE, W. Characteristics of soybeans as affected by soaking conditions. Food Science Technology, v. 36, n. 1, p. 143-151, 2003.

PELEG, M. An empirical model for the description of moisture sorption curves. Journal of Food Science, v. 52, p. 1216-1219, 1988. http:// dx.doi.org/10.1111/j.1365-2621.1988.tb13565.x

RAHMAN, S. Food properties handbook. Boca Ratón: CRC Press LLC, 1995. $500 \mathrm{p}$

RESENDE, O.; CORRÊA, P. C. Modelagem matemática do processo de hidratação de sementes de feijão. Acta Scientiarum Agronomy, v. 29, n. 3, p. 373-378, 2007.

RESIO, A. N. C.; AGUERRE, R. J.; SUAREZ, C. Study of some factors affecting water absorption by amaranth grain during soaking. Journal of Food Engineering, v. 60, n. 4, p. 391-396, 2003. http:// dx.doi.org/10.1016/S0260-8774(03)00062-1

RESIO, A. N. C.; AGUERRE, R. J.; SUAREZ, C. Analysis of simultaneous water absorption and water-starch reaction during soaking of amaranth grain. Journal of Food Engineering, v. 68, n. 2, p. 265-270, 2005. http://dx.doi.org/10.1016/j.jfoodeng.2004.05.043

RIOS, A. O.; ABREU, C. M. P.; CORRÊA, A. D. Efeito da estocagem e das condições de colheita sobre algumas propriedades físicas, químicas e nutricionais de três cultivares de feijão (Phaseolus vulgaris L.). Ciência e Tecnologia de Alimentos, v. 23, p. 39-45, 2003. Suplemento.

SILVA, J. S.; CORRÊA, P. C. Estrutura, composição e propriedades dos grãos In: SILVA, J. S. Secagem e armazenagem de produtos agrícolas. Viçosa, 2000. p. 21-37.

TURHAN, M.; SAYAR, S.; GUNASEKARAN, S. Application of Peleg's model to study water absorption in chickpea during soaking. Journal of Food Engineering, v. 53, n. 2, p. 153-159, 2002. http:// dx.doi.org/10.1016/S0260-8774(01)00152-2

VERMA, R. C.; PRASAD, S. Kinetics of absorption of water by maize grains. Journal of Food Engineering, v. 39, n. 4, p. 395-400, 1999. http://dx.doi.org/10.1016/S0260-8774(99)00027-8

VIEIRA, R. F.; VIEIRA, C.; ANDRADE, G. A. Comparações agronômicas de feijões dos gêneros Vigna e Phaseolus com o feijão-comum (Phaseolus vulgaris L.). Pesquisa Agropecuária Brasileira, v. 27, n. 6, p. 841-850, 1992.

YOUSIF, A. M. et al. Effect of storage of adzuki bean (Vigna angularis) on starch and protein properties. Lebensmittel-Wissenschaft undTechnologie, v. 36, n. 6, p. 601-607, 2003. 